\title{
PENGARUH ORIENTASI PASAR DAN INOVASI PRODUK TERHADAP KEUNGGULAN BERSAING DAN KINERJA PEMASARAN PENGOLAHAN RUMPUT LAUT DI WAKATOBI
}

\author{
Oktavinus $^{1}$ \\ Program Studi Ilmu Manajemen, Program Pascasarjana Universitas Halu Oleo \\ Sudirman Zaid ${ }^{2}$ \\ Program Studi manajemen, Fakultas Ekonomi Dan Bisnis Universitas Halu Oleo \\ Hayat Yusuf ${ }^{3}$ \\ Program Studi manajemen, Fakultas Ekonomi Dan Bisnis Universitas Halu Oleo
}

\begin{abstract}
The purpose of this study was to find out and analyze the influence of market orientation and product innovation on competitive advantage and the performance of marketing seaweed processing in Wakatobi. The variables of this study are market orientation, product innovation, competitive advantage and marketing performance. The population of this study was seaweed farmer groups with the number of respondents 48. The analysis used was descriptive and inferential analysis with the help of path analysis tools.

The results of this study indicate that the direct influence of market orientation, product innovation and competitive advantage has a positive and significant effect on the performance of seaweed processing marketing in Wakatobi. While the indirect influence of market orientation and product innovation on marketing performance through competitive advantage plays a role in pseudo mediating.
\end{abstract}

Keywords: market orientation, product innovation, competitive advantage and marketing performance.

Tujuan penelitian ini adalah untuk mengetahui dan menganalisis pengaruh orientasi pasar dan inovasi produk terhadap keunggulan bersaing dan kinerja pemasaran pengolahan rumput laut di Wakatobi. Variabel penelitian ini adalah orientasi pasar, inovasi produk, keunggulan bersaing dan kinerja pemasaran. Populasi penelitian ini adalah kelompok petani rumput laut dengan jumlah responden 48. Analisis yang digunakan adalah analisis deskriptif dan inferensial dengan bantuan alat analisis jalur.

Hasil penelitian ini menunjukkan bahwa pengaruh langsung orientasi pasar, inovasi produk dan keunggulan bersaing berpengaruh positif dan signifikan terhadap kinerja pemasaran pengolahan rumput laut di Wakatobi. Sedangkan pengaruh tidak langsung orientasi pasar dan inovasi produk terhadap kinerja pemasaran melalui keunggulan bersaing berperan dalam memediasi semu.

Kata Kunci: orientasi pasar, inovasi produk, keunggulan bersaing dan kinerja pemasaran.

Pendahuluan

Dalam dunia bisnis, menambah jumlah pelanggan dan mempertahankannya sebagai pelanggan yang loyal bisa menjadi salah satu ukuran keberhasilan usaha. Hal ini terkait dengan efektivitas program pemasaran dan strategi yang diterapkannya. Kegiatan pemasaran tidak hanya dalam konteks transaksi 
antara usaha dengan pelanggan, lebih dari itu perusahaan juga harus menjalin hubungan yang lebih dekat dengan pelanggan dengan cara lebih memahami apa harapan pelanggan.

Persaingan bisnis yang begitu ketat mengharuskan perusahaan untuk lebih meningkatkan kinerja pemasaran perusahaan, karena keberhasilan suatu produk akan berpengaruh pada kinerja pemasarannya. Kinerja pemasaran merupakan ukuran keberhasilan perusahaan yang diukur pada jangka waktu yang telah ditentukan sebagai nilai dari aktivitas yang telah disusun dan dilaksanakan untuk mengetahui apakah strategi yang disusun dan pelaksanaannya sudah tepat atau sebaliknya (Puspitasari, 2015).

Dengan semakin ketatnya persaingan tersebut maka perusahaan harus memahami apa dan bagaimana cara untuk mengelola berbagai sumber daya yang dimilikinya. Kunci penting untuk memenangkan persaingan terletak pada kemampuan perusahaan untuk menciptakan keunggulan bersaing. Narver dan Slater (1990, p.21) menyatakan bahwa keunggulan bersaing dapat dicapai apabila perusahaan mampu memberikan nilai yang lebih kepada pelanggan dari apa yang diberikan oleh pesaingnya.

Terkait dengan itu ada dua strategi yang umumnya digunakan perusahaan yaitu orientasi pasar (Narver and Slater, 1995) dan inovasi (Han et at., 1998). Menurut Kohli dan Jaworski (1990), orientasi pasar merupakan budaya perusahaan yang bisa membawa pada meningkatnya kinerja pemasaran. Sedangkan inovasi produk adalah untuk memenuhi permintaan pasar sehingga produk inovasi merupakan salah satu yang dapat digunakan sebagai keunggulan bersaing bagi perusahaan (Han et at., 1998).

Menghadapi kondisi persaingan yang ketat maka perusahaan juga harus menciptakan keunggulan bersaing yang merupakan strategi yang menguntungkan bagi perusahaan yang melakukan kerjasama untuk berkompetisi lebih efektif dalam pasar (Dewi 2006, Djodjobo dan Tawas, 2014). Keunggulan bersaing berkaitan dengan cara bagaimana perusahaan memilih dan benar-benar dapat melaksanakan strategi generic ke dalam praktik.

Hartanti.et,all (2013) berpendapat bahwa untuk meningkatkan kinerja pemasaran dibangun oleh inovasi antara lain melalui inovasi teknis dan inovasi produk. Konsekuensinya akan meningkatkan kinerja pemasaran berupa volume penjualan yang meningkat, jumlah pelanggan yang bertambah serta kemampuan untuk menciptakan laba kepada pemiliknya.

Tingginya tingkat persaingan tidak hanya dialami oleh industri - industri besar saja tetapi juga dialami oleh industri kecil dan menengah di Indonesia, seperti industri kecil dan menengah yang ada di kabupaten Wakatobi. Salah satu industri pengolahan yang terus berkembang di wakatobi yaitu industri pengolahan rumput laut. Penelitian ini berfokus pada industri pengolahan yang ada di Kabupaten Wakatobi. Kabupaten Wakatobi memberikan potensi yang sangat besar. Industri pengolahan di Kabupaten Wakatobi perlu melakukan suatu inovasi pada produk yang dihasilkan dengan berorientasi pada konsumen karena pengetahuan tentang kebutuhan dan keinginan konsumen merupakan kunci sukses dari inovasi produk yang akan dihasilkan yang kemudian akan mampu menghadapi persaingan dan akan berpengaruh pada kinerja pemasaran IKM itu sendiri. Tingginya kontribusi industri pengolahan disebabkan karena Kabupaten Wakatobi merupakan daerah tujuan pariwisata, dimana produk dari pengolahan rumput laut sangat dibutuhkan untuk memenuhi kebutuhan pelanggan sebagai bentuk olahan makanan. Tidak hanya untuk sektor pariwisata saja tetapi juga dibutuhkan oleh masyarakat luas untuk melengkapi kebutuhan 
sehari-hari. Bertolak dari fenomena pentingnya orientasi pasar, inovasi dan keunggulan bersaing terhadap kinerja pemasaran dan hasil kajian empiris yang telah dipaparkan maka tujuan penelitian ini adalah:

1. Untuk mengetahui dan menganalisis pengaruh orientasi pasar terhadap keunggulan bersaing pada pengolah rumput laut di Wakatobi.

2. Untuk mengetahui dan menganalisis pengaruh orientasi pasar terhadap kinerja pemasaran pada pengolah rumput laut di Wakatobi.

3. Untuk mengetahui dan menganalisis pengaruh inovasi produk terhadap keunggulan bersaing pada pengolah rumput laut di Wakatobi.

4. Untuk mengetahui dan menganalisis pengaruh inovasi produk terhadap kinerja pemasaran pada pengolah rumput laut di Wakatobi.

5. Untuk mengetahui dan menganalisis pengaruh keunggulan bersaing terhadap kinerja pemasaran pada $\begin{array}{llll}\text { pengolah lamput di lautobi. } & \end{array}$

Kajian Literatur dan Hipotesis

Narver dan Slater (1990, p. 21-22) menyatakan bahwa orientasi pasar terdiri dari 3 komponen perilaku yaitu orientasi pelanggan, orientasi pesaing dan koordinasi interfungsional. Orientasi pelanggan dan orientasi pesaing termasuk semua aktivitasnya dilibatkan dalam memperoleh informasi tentang pembeli dan pesaing pada pasar yang dituju dan menyebarkan melalui bisnis, sedangkan koordinasi interfungsional didasarkan pada informasi pelanggan serta pesaing dan terdiri dari usaha bisnis yang terkoordinasi. Lebih jauh dijelaskan bahwa orientasi pelanggan diartikan sebagai pemahaman yang memadai tentang target beli pelanggan dengan tujuan agar dapat menciptakan nilai unggul bagi pembeli secara terus menerus. Pemahaman disini mencakup pemahaman terhadap seluruh rantai nilai pembeli, baik pada saat terkini maupun pada saat perkembangannya di masa yang akan datang. Upaya ini dapat dicapai melalui proses pencarian informasi tentang pelanggan (Uncles, 2000, p.1). Dengan adanya informasi tersebut maka perusahaan penjual (seller) akan memahami siapa saja pelanggan potensialnya,baik pada saat ini maupun pada masa yang akan datang dan apa yang mereka inginkan untuk saat ini dan saat mendatang.

Orientasi pesaing berarti bahwa perusahaan yang berorientasi pesaing sering dilihat sebagai perusahaan yang mempunyai strategi bagaimana membagikan informasi mengenai pesaing, bagaimana merespon tindakan pesaing dan juga bagaimana manajemen puncak didalam mendiskusikan strategi pesaing (Narver dan Slater, 1990, p. 21). Orientasi pada pesaing dapat dimisalkan bahwa tenaga penjualan akan berupaya untuk mengumpulkan informasi mengenai pesaing dan mambagi informasi itu kepada fungsi - fungsi lain dalam perusahaan misalnya kepada devisi riset dan pengambangan produk atau mendiskusikan dengan pimpinan perusahaan bagaimana kekuatan pesaing dan strategi - strategi yang dikembangkan (Ferdinand, 2000, p. 18).

Narver dan Slater (1990, p.22) menyatakan bahwa orientasi pesaing berarti bahwa perusahaan memahami kekuatan jangka pendek, kelemahan, kemampuan jangka panjang dan strategi dari para pesaing potensialnya. Pemahaman ini termasuk apakah pesaing menggunakan teknologi baru guna mempertahankan pelanggan yang ada. Perusahaan yang berorientasi pesaing sering dilihat sebagai perusahaan yang mempunyai strategi dan memahami bagaimana cara memperoleh dan membagikan informasi mengenai pesaing, bagaimana merespon tindakan pesaing dan juga bagaimana manajemen puncak menanggapi strategi pesaing (Jaworski dan Kohli, 1993, p. 55).

Narver dan Slater (1990, p. 22) menyatakan bahwa koordinasi interfungsional merupakan kegunaan dari sumber daya perusahaan yang terkoordinasi dalam menciptakan nilai unggul bagi pelanggan yang ditargetkan. Koordinasi interfungsional menunjuk pada aspek khusus dari struktur organisasi yang mempermudah komunikasi antar fungsi organisasi yang berbeda. 
Koordinasi interfungsional didasarkan pada informasi pelanggan dan pesaing serta terdiri dari upaya penyelarasan bisnis, secara tipikal melibatkan lebih dari departemen pemasaran, untuk menciptakan nilai unggul bagi pelanggan. Koordinasi interfungsional dapat mempertinggi komunikasi dan pertukaran antara semua fungsi organisasi yang memperhatikan pelanggan dan pesaing, serta untuk menginformasikan trend pasar yang terkini. Hal ini membantu perkembangan baik kepercayaan maupun kemandirian diantara unit fungsional yang terpisah, yang pada akhirnya menimbulkan lingkungan perusahaan yang lebih mau menerima suatu produk yang benar-benar baru yang didasarkan dari kebutuhan pelanggan.

Inovasi produk merupakan suatu cara yang penting bagi perusahaan agar tetap dapat beradaptasi dengan pasar, teknologi, serta pesaingan (Dourgerty, 1996). Inovasi produk menunjukkan pada pengembangan dan pengenalan produk baru atau dikembangkan yang berhasil di pemasaran (Nelly et al., 2001). Inovasi produk dapat berupa perubahan desain, komponen dan arsitektur produk. Beberapa indikator yang digunakan untuk menilai inovasi produk adalah kultur inovasi, inovasi teknis, dan inovasi produk. Kultur inovasi adalah budaya inovasi yang ada di perusahaan. Inovasi teknis adalah inovasi pada proses perusahaan dalam menghasilkan produk. Inovasi produk adalah kemampuan perusahaan untuk menghasilkan produk sesuai keinginan pelanggan.

Keunggulan bersaing adalah kemampuan perusahaan untuk menciptakan nilai unggul dengan memanfaatkan berbagai sumber daya yang dimilikinya (Markland, Droge dan Vickery, 1995). Strategi pemasaran yang jitu harus dibarengi dengan perencanaan daya saing perusahaan yang handal (Triton PB, 2008: 97). Keunggulan bersaing adalah sekumpulan keistimewaan dari suatu perusahaan dan produknya yang diterima oleh target pasar sebagai faktor yang penting dalam persaingan (Lamb, Hair, McDaniel, 2001). Terdapat tiga jenis keunggulan bersaing yaitu keunggulan bersaing biaya (cost competitive advantage), keunggulan bersaing diferensial dan keunggulan bersaing ceruk (Niche Competitive Advantage). Beberapa indikator yang digunakan untuk mengukur keunggulan bersaing adalah keunikan produk, kualitas produk, dan harga bersaing. Keunikan produk adalah keunikan produk perusahaan yang memadukan nilai seni dengan selera pelanggan. Kualitas produk adalah kualitas desain dari produk perusahaan. Sedangkan harga bersaing adalah kemampuan perusahaan untuk menyesuaikan harga produknya dengan harga umum di pasaran.

Kinerja pemasaran merupakan ukuran prestasi yang diperoleh dari aktifitas proses pemasaran secara menyeluruh dari sebuah perusahaan atau organisasi. Selain itu, kinerja pemasaran juga dapat dipandang sebagai sebuah konsep yang digunakan untuk mengukur sampai sejauh mana prestasi pasar yang telah dicapai oleh suatu produk yang dihasilkan perusahaan. Ferdinand (2000, p.23) menyatakan bahwa kinerja pemasaran merupakan faktor yang seringkali digunakan untuk mengukur dampak dari strategi yang diterapkan perusahaan. Strategi perusahaan selalu diarahkan untuk menghasilkan kinerja pemasaran (seperti volume penjualan dan tingkat pertumbuhan penjualan ) yang baik dan juga kinerja keuangan yang baik. Selanjutnya Ferdinand juga menyatakan bahwa kinerja pemasaran yang baik dinyatakan dalam tiga besaran utama nilai, yaitu nilai penjualan, pertumbuhan penjualan, dan porsi pasar. Beberapa indikator yang digunakan dalam menilai kinerja pemasaran adalah volume penjualan, pertumbuhan pelanggan, dan kemampulabaan. Volume penjualan adalah volume penjualan dari produk perusahaan. Pertumbuhan pelanggan adalah tingkat pertumbuhan pelanggan perusahaan. Kemampulabaan adalah besarnya keuntungan yang diperoleh

oleh

perusahaan.

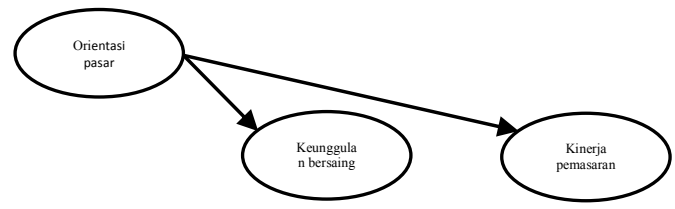




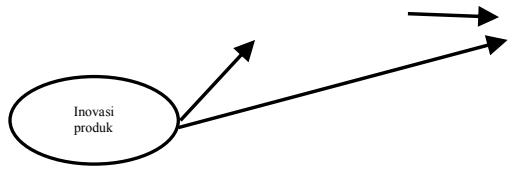

Kerangka Konseptual

Hipotesis Penelitian

1. Orientasi pasar berpengaruh signifikan terhadap keunggulan bersaing pada pengolah rumput laut di wakatobi.

2. Orientasi pasar berpengaruh signifikan terhadap kinerja pemasaran pada pengolah rumput laut di wakatobi.

3. Inovasi produk berpengaruh signifikan terhadap keunggulan bersaing pada pengolah rumput laut di wakatobi.

4. Inovasi produk berpengaruh signifikan terhadap kinerja pemasaran pada pengolah rumput laut di wakatobi.

5. Keunggulan bersaing berpengaruh signifikan terhadap kinerja pemasaran pada pengolah rumput laut di wakatobi.

\section{Metode Penelitian}

Berdasakan sifat permasalahan dan tujuan yang ingin di capai, penelitian ini bersifat explanatory. Suatu penelitian yang bersifat explanatory umumnya bertujuan untuk mengetahui faktor/pengaruh penyusunan dari suatu dimensi kehidupan (Solimun, 2002). Adapun tipologi penelitian yang bersifat explanatory yaitu pengaruh orientasi pasar, dan inovasi produk, terhadap keunggulan bersaing dan kinerja pemasaran yang memberikan penjelasan hubungan kausalitas antar variabel melalui pengujian hipotesis.

Objek dan Waktu Penelitian

Lokasi penelitian adalah di Kabupaten Wakatobi. Jangka waktu penelitian adalah 2 bulan.

\section{Sampel Penelitian}

Populasi dalam penelitian ini adalah seluruh kelompok/petani pengolah rumput laut berjumlah 48 orang. Teknik pengambilan responden berdasarkan teknik sensus, yaitu mengambil semua jumlah populasi untuk dijadikan responden.

Metode Pengumpulan Data

Berdasakan tujuan penelitian ini, maka beberapa data dan informasi yang relevan diperlukan dengan menggunakan metode pengumpulan data menggunakan kuesioner, wawancara dan dokumentasi.

Skala dan Pengukuran Data

Penentuan skala Likert menggunakan skala 1 sampai dengan 5, yaitu:

- "sangat tidak setuju " diberi bobot 1

- "tidak setuju" diberi bobot 2

- "netral" diberi bobot 3 
- "setuju" diberi bobot 4

- "sangat setuju" diberi bobot 5

Defenisi Operasional Variabel

1. Orientasi pasar adalah kemauan perusahaan untuk menerapkan budaya yang berorientasi pada pasar. Indikatro dari variabel ini adalah:

a. Orientasi pelanggan adalah kemauan perusahaan untuk memahami para pelangganya.

b. Orientasi pesaing adalah kemauan perusahaan/kelompok untuk memonitor para pesaingnya.

c. Informasi pasar adalah upaya perusahaan untuk mencari informasi tentang kondisi pasar.

2. Inovasi produk adalah kemampuan perusahaan untuk menciptakan produk-produk yang inovatif. Indikator dari variabel ini adalah:

a. Kultur inovasi produk adalah budaya inovasi yang ada di perusahaan untuk selalu menciptakan produk-produk baru.

b. Inovasi teknis adalah inovasi pada proses perusahaan dalam menghasilkan produk baru.

c. Inovasi produk adalah kemampuan perusahaan untuk menghasilkan produk baru yang sesuai keinginan pelanggan.

3. Keuanggulan bersaing adalah kemampuan perusahaan dalam menciptakan nilai unggul guna menghadapi persaingan. Indikator variabel ini adalah:

a. Keunikan produk adalah keunikan produk perusahaan sehingga membedakannya dari produk pesaing atau produk umum di pasaran.

b. Kualitas produk adalah kualitas dari produk yang berhasil diciptakan oleh perusahaan.

c. Harga bersaing adalah kemampuan perusahaan untuk menghasilkan produk dengan harga yang mampu bersaing di pasaran.

4. Kinerja pemasaran adalah kinerja perusahaan ditinjau dari aspek pemasarannya. Indikator variabel ini adalah:

a. Volume penjualan adalah volume atau jumlah penjualan produk yang berhasil dicapai oleh perusahaan

b. Pertumbuhan pelanggan adalah tingkat pertumbuhan pelanggan yang berhasil dicapai oleh perusahaan

c. Kemampulabaan adalah besarnya keuntungan penjualan produk yang berhasil diperoleh oleh perusahaan.

\section{Metode Analisis Data}

Untuk menganalisa data, pencapain tujuan penelitian serta pengujian hipotesis yang diajukan, maka data yang diperoleh selanjutnya akan diolah sesuai dengan kebutuhan analisis. Teknik yang digunakan adalah teknik analisis statistik deskriptif dan statistik inferensial. Analisis statistik inferensial yang dipilih dan digunakan adalah analisis jalur (path analysis) dengan bantuan software AMOS 18.0.

\section{Hasil Penelitian}

\section{Analisis Statistik Deskriptif}


Deskriptif variabel penelitian bertujuan untuk menginterprestasikan mengenai distribusi frekwensi jawaban responden dari data yang telah dikumpulkan. Gambaran data tanggapan responden dari hasil penelitian mengenai keempat variabel yang diteliti dengan menggunakan rata-rata skor jawaban responden diuraikan sebagai berikut:

Orientasi Pasar

Variabel orientasi pasar yang diukur dengan menggunakan 3 (tiga) item indikator pernyataan untuk mengukur variabel orientasi pasar yang digunakan dalam penelitian ini. Indikator pengukuran adalah diadopsi dari teori yang dikemukakan oleh Narver dan Slater (1990) dan Uncles, (2000). Dari 3 (tiga) item variabel orientasi pasar nilai rerata jawaban responden atas variabel orientasi pasar adalah sebesar 4,19 hal ini menggambarkan bahwa mayoritas responden menyatakan setuju dan sangat setuju terhadap orientasi pelanggan, orientasi pesaing dan informasi pasar. Untuk itu yang perlu dilakukan pada para petani pengolah rumput laut adalah pemahaman yang memadai tentang target beli pelanggan dengan meletakkan kepentingan pelanggan pada urutan yang pertama sementara tidak meniadakan stakeholder yang lain seperti pemilik, manajer dan karyawan dengan tujuan agar dapat menciptakan nilai unggul bagi pembeli secara terus menerus.

\section{Inovasi Produk}

Variabel inovasi produk diukur dengan menggunakan 3 (tiga) item indikator. Pengukuran inovasi produk yang digunakan dalam penelitian ini adalah diadopsi dari teori yang dikemukakan oleh Bharadwaj et all (1993) yaitu : kultur inovasi produk, inovasi teknis dan inovasi produk. Dari 3 (tiga) indikator variabel inovasi produk nilai rerata jawaban responden setiap indikator adalah sebesar 4,20. Hal ini menggambarkan bahwa mayoritas responden merasa setuju bahwa perusahaan harus menciptakan produk-produk yang inovatif melalui Kultur inovasi produk, inovasi teknis dan inovasi produk. Adapun strategi yang harus dilakukan oleh kelompok petani pengolah rumput laut adalah selalu berinovatif dalam melakukan perbaikan, menyajikan sesuatu yang baru/unik yang berbeda dengan yang sudah ada dengan cara gagasan baru dan upaya perbaikan.

\section{Keunggulan Bersaing}

Variabel keunggulan bersaing diukur dengan 3 (tiga) item indikator pernyataan. Pengukuran keunggulan bersaing yang digunakan dalam penelitian ini adalah diadopsi dari teori yang dikemukakan oleh Styagraha (1994,) yaitu: keunikan produk, kualitas produk dan harga bersaing. Dari 3 (tiga) indikator variabel keunggulan bersaing nilai rerata jawaban responden adalah sebesar 4,25. Hal ini menggambarkan bahwa mayoritas responden merasa setuju dengan kemampuan perusahaan dalam menciptakan nilai unggul guna menghadapi persaingan melalui keunikan produk, kualitas produk dan harga. Strategi yang perlu dilakukan adalah pendekatan diferensiasi, artinya bahwa pemilihan produk di antara banyaknya tawaran yang ada di pasar selalu didasarkan pada adanya perbedaan, baik secara implisit maupun eksplisit. Literatur Psikologi merujuk kepada fakta bahwa perbedaan mencolok yang terkait dengan suatu produk akan merangsang daya ingat karena perbedaan tersebut akan diapresiasikan secara intelektual Perusahaan jasa perlu melakukan diferensiasi melalui inovasi yang bersifat prevemptive dalam jangka panjang. Prevemptive di sini maksudnya adalah implementasi suatu strategi yang baru bagi suatu bisnis tertentu. Karena merupakan yang pertama, maka dapat menghasilkan keterampilan atau aset yang dapat merintangi, mencegah, atau menghalangi para pesaing untuk melakukan duplikasi atau membuat tandingannya (Macmillan dalam Aaker, 1992) dalam Tjiptono (2001).

Kinerja Pemasaran 
Variabel kinerja pemasaran dalam penelitian ini diukur oleh 3 (tiga) item indikator pernyataan, yaitu volume penjualan, pertumbuhan pelanggan dan kemampulabaan. Dari 3 (tiga) indikator variabel kinerja pemasaran nilai rerata jawaban responden adalah 4,29. Hal ini menggambarkan bahwa mayoritas responden merasa setuju bahwa kinerja perusahaan ditinjau dari aspek pemasarannya dapat diukur melalui volume penjualan, pertumbuhan pelanggan dan kemampulabaan. Strategi yang perlu dilakukan adalah inovasi produk. produk tak ubahnya seperti manusia semakin lama semakin tua dan tidak menarik lagi, upaya yang dilakukan melalui regenerasi dan pemutakhiran terhadap produk tersebut. Hal tersebut menunjukkan bahwa product development yang tercermin dalam inovasi produk dan diversifikasi dalam usaha kecil menengah mempunyai dampak yang sangat signifikan dalam mencapai kinerja pemasaran.

\section{Analisis Statistik Inferensial}

Data hasil penelitian diuji dengan menggunakan model analisis jalur (path analysis) dalam hal ini untuk melihat pengaruh langsung antar variabel yang diteliti yang dibangun berdasarkan model pada kerangka konseptual penelitian. Berdasarkan hasil uji analisis Path melalui paket program komputer $A M O S$ maka dapat diketahui pengaruh secara langsung variabel:

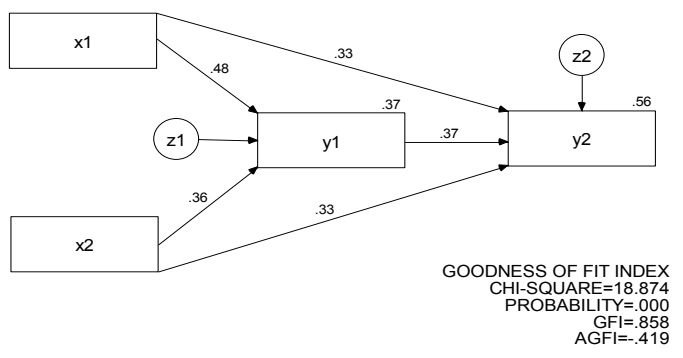

Gambar 1. Model Analisis Jalur

Tabel 1. Hasil Uji Indirect Path

\begin{tabular}{|c|c|c|c|c|c|}
\hline $\begin{array}{c}\text { Variabel } \\
\text { Independen }\end{array}$ & $\begin{array}{c}\text { Variabel } \\
\text { Intervening }\end{array}$ & $\begin{array}{c}\text { Variabel } \\
\text { Dependen }\end{array}$ & $\begin{array}{c}\text { Koefisien } \\
\text { path } \\
\text { direct }\end{array}$ & Probability & Ket \\
\hline $\begin{array}{c}\text { Orientasi } \\
\text { pasar }\end{array}$ & $\begin{array}{c}\text { Keunggulan } \\
\text { bersaing }\end{array}$ & & 0,483 & 0,000 & Sig \\
\hline $\begin{array}{c}\text { Orientasi } \\
\text { pasar }\end{array}$ & Kinerja \\
\hline $\begin{array}{c}\text { Inovasi } \\
\text { produk }\end{array}$ & $\begin{array}{c}\text { Keunggulan } \\
\text { bersaing }\end{array}$ & 0,334 & 0,011 & Sig \\
\hline $\begin{array}{c}\text { Inovasi } \\
\text { produk }\end{array}$ & $\begin{array}{c}\text { Kinerja } \\
\text { pemasaran }\end{array}$ & 0,326 & 0,010 & Sig. \\
\hline & $\begin{array}{c}\text { Keunggulan } \\
\text { bersaing }\end{array}$ & $\begin{array}{c}\text { Kinerja } \\
\text { pemasaran }\end{array}$ & 0,368 & 0,002 & Sig. \\
\hline
\end{tabular}

Sumber: Data Primer diolah, 2019

Berdasarkan Tabel 1. dapat diketahui terdapat jalur hipotesis yang terdukung data empiris yang diterima dan ditolak adalah:

H 1: Orientasi pasar berpengaruh positif dan signifikan terhadap keunggulan bersaing.

H 2: Orientasi pasar berpengaruh positif dan signifikan terhadap kinerja pemasaran.

$\mathrm{H} 3$ : Inovasi produk berpengaruh positif dan signifikan terhadap keunggulan bersaing.

$\mathrm{H} 4$ : Inovasi produk berpengaruh positif dan signifikan terhadap kinerja pemasaran.

H 5: Keunggulan bersaing positif dan signifikan terhadap kinerja pemasaran. 
Analisis hubungan tidak langsung (indirect effect) antar konstruk dari model dapat dibandingkan untuk mengevaluasi hubungan setiap konstruk secara langsung dikalikan dengan pengaruh langsung variabel

lainnya.

Tabel 2. Hasil Uji Indirect Path.

\begin{tabular}{|l|c|c|c|c|c|}
\hline $\begin{array}{c}\text { Variabel } \\
\text { Independen }\end{array}$ & $\begin{array}{c}\text { Variabel } \\
\text { Intervening }\end{array}$ & $\begin{array}{c}\text { Variabel } \\
\text { Dependen }\end{array}$ & $\begin{array}{c}\text { Koefisien } \\
\text { path } \\
\text { indirect }\end{array}$ & $\begin{array}{c}\text { Total } \\
\text { Effect }\end{array}$ & Ket \\
\hline $\begin{array}{l}\text { Orientasi } \\
\text { pasar }\end{array}$ & $\begin{array}{c}\text { Keunggulan } \\
\text { bersaing }\end{array}$ & $\begin{array}{c}\text { Kinerja } \\
\text { Pemasaran }\end{array}$ & 0,178 & 0,512 & $\begin{array}{c}\text { Mediasi } \\
\text { Semu }\end{array}$ \\
\hline $\begin{array}{l}\text { Inovasi } \\
\text { produk }\end{array}$ & $\begin{array}{c}\text { Keunggulan } \\
\text { bersaing }\end{array}$ & $\begin{array}{c}\text { Kinerja } \\
\text { Pemasaran }\end{array}$ & 0,134 & 0,460 & $\begin{array}{c}\text { Mediasi } \\
\text { Semu }\end{array}$ \\
\hline
\end{tabular}

Berdasarkan Tabel 2 dapat diketahui bahwa keunggulan bersaing berperan dalam memediasi semu pengaruh orientasi pasar secara tidak langsung terhadap kinerja pemasaran, dan keuanggulan bersaing berperan dalam memediasi semu pengaruh inovasi produk secara tidak langsung terhadap kinerja pemasaran.

Pengujian Hipotesis

1. Pengaruh orientasi pasar terhadap keunggulan bersaing diperoleh nilai koefisien jalur sebesar 0,483 dengan nilai probalitas 0,000 yang berarti $\mathrm{p}<\alpha=0,05$ artinya variabel orientasi pasar berpengaruh positif dan signifikan terhadap variabel keunggulan bersaing dengan kontribusi efek variabel orientasi pasar terhadap keunggulan bersaing sebesar 0,483 mempunyai makna bahwa 48,3\% yang terjadi kecenderungan meningkatnya keunggulan bersaing pengolah rumput laut disebabkan oleh orientasi pasar yang baik.

2. Pengaruh orientasi pasar terhadap kinerja pemasaran diperoleh nilai koefisien jalur sebesar 0,334 dengan nilai probalitas 0,011 yang berarti $\mathrm{p}<\alpha=0,05$ artinya variabel orientasi pasar berpengaruh positif dan signifikan terhadap kinerja pemasaran dengan kontribusi efek variabel orientasi pasar terhadap kinerja pemasaran sebesar 0,334 mempunyai makna bahwa 33,4\% terjadi kecenderungan meningkatnya kinerja pemasaran disebabkan oleh orientasi pasar yang baik.

3. Pengaruh inovasi produk terhadap keunggulan bersaing diperoleh nilai koefisien jalur sebesar 0,364 dengan nilai probabilitas 0,010 yang berarti $\mathrm{p}<\alpha=0,05$ artinya inpvasi produk berpengaruh positif dan signifikan terhadap keunggulan bersaing dengan kontribusi efek inovasi produk terhadap keunggulan bersaing sebesar 0,364 mempunyai makna bahwa $36,4 \%$ peranan inovasi produk cukup berarti dalam mempengaruhi meningkatnya keunggulan bersaing pengolah rumput laut.

4. Pengaruh inovasi produk terhadap kinerja pemasaran diperoleh nilai koefisien jalur sebesar 0,326 dengan nilai probabilitas 0,010 yang berarti $\mathrm{p}>\alpha=0,05$ artinya inovasi produk berpengaruh positif dan signifikan terhadap kinerja pemasaran dengan kontribusi efek inovasi produk terhadap kinerja pemasaran sebesar 0,326 mempunyai makna bahwa 32,6\% peranan inovasi produk dalam mempengaruhi meningkatnya kinerja pemasaran.

5. Pengaruh keunggulan bersaing terhadap kinerja pemasaran diperoleh nilai koefisien jalur sebesar 0,368 dengan nilai probalitas 0,002 yang berarti $\mathrm{p}<\alpha=0,05$ artinya keunggulan bersaing berpengaruh positif dan signifikan terhadap kinerja pemasaran dengan kontribusi efek keunggulan bersaing terhadap kinerja pemasaran sebesar 0,368 mempunyai makna bahwa 36,8 \% yang terjadi kecenderungan meningkatnya kinerja pemasaran pengolah rumput laut disebabkan oleh keunggulan bersaing yang baik. 
6. Pengujian dengan standardized regresion weigh diperoleh bahwa ada pengaruh orientasi pasar terhadap keunggulan bersaing dengan nilai koefisien direct effect sebesar 0,483 dan pengaruh keunggulan bersaing terhadap kinerja pemasaran dengan nilai koefisien direct effect sebesar 0,368. Berdasarkan hasil pengujian tersebut, maka dapat disimpulkan bahwa keunggulan bersaing dapat memediasi pengaruh orientasi pasar terhadap kinerja pemasaran dan besarnya koefisien pengaruh tidak langsung orientasi pasar terhadap kinerja pemasaran melalui keunggulan bersaing dibuktikan dengan nilai Standardized Indirect Effects sebesar 0,178.

7. Pengujian dengan standardized regresion weigh diperoleh bahwa ada pengaruh inovasi produk terhadap keunggulan bersaing dengan nilai koefisien direct effect sebesar 0,364 dan pengaruh keunggulan bersaing terhadap kinerja pemasaran dengan nilai koefisien direct effect sebesar 0,368. Berdasarkan hasil pengujian tersebut, maka dapat disimpulkan bahwa keunggulan bersaing dapat memediasi pengaruh inovasi produk terhadap kinerja pemasaran dan besarnya koefisen pengaruh tidak langsung inovasi produk terhadap kinerja pemasaran melalui keunggulan bersaing dibuktikan dengan nilai Standardized Indirect Effects sebesar 0,134.

\section{Pembahasan hasil Penelitian}

\section{Pengaruh Orientasi Pasar Terhadap Keunggulan Bersaing}

Pengaruh orientasi pasar berpengaruh positif dan signifikan terhadap keuanggulan bersaing. Artinya bahwa Pentingnya orientasi pasar merupakan sumber keunggulan bersaing yang berkelanjutan di tengah persaingan yang semakin nyata. Puspitasari (2015) menyatakan bahwa orientasi pasar berpengaruh secara signifikan dan positif terhadap keunggulan bersaing. Hal ini menunjukan bahwa kemauan perusahaan untuk menerapkan strategi orientasi pasar akan berdampak pada kemampuan perusahaan untuk bersaing dengan perusahaan lainnya. Penelitian Usvita (2015) menyatakan bahwa orientasi pasar berpengaruh positif dan signifikan terhadap keunggulan bersaing.

Orientasi pasar merupakan sesuatu yang penting bagi perusahaan sejalan dengan meningkatnya persaingan global dan perubahan dalam kebutuhan pelanggan dimana perusahaan menyadari bahwa mereka harus selalu dekat dengan pasarnya. Orientasi pasar merupakan budaya bisnis dimana organisasi mempunyai komitmen untuk terus berkreasi dalam menciptakan nilai unggul bagi pelanggan. Natver dan Slater ( 1990 ) mendefinisikan orientasi pasar sebagai budaya organisasi yang paling efektif dalam menciptakan perilaku penting untuk penciptaan nilai unggul bagi pembeli serta kinerja dalam bisnis. Sedangkan Uncles (2000) mengartikan orientasi pasar sebagal suatu proses dan aktivitas yang berhubungan dengan penciptaan dan pemuasan pelanggan dengan cara terus menilai kebutuhan dan keinginan pelanggan. Wahyono (2002), orientasi pasar merupakan budaya organisasi yang efektif dan efisien untuk menciptakan perilaku yang dibutuhkan untuk menciptakan nilai superior bagi pembeli dan kinerja superior bagi perusahaan.

Hasil ini didukung oleh penelitian yang dilakukan oleh Renita Helia, Naili Farida, Bulan Prabawani (2015), Bernadeta Dewi Kusuma Jati, Ngatno, (2015), membuktikan bahwa orientasi pasar memiliki pengaruh positif terhadap keunggulan bersaing. Perusahaan yang menerapkan orientasi pasar memiliki kelebihan dalam hal pengetahuan pelanggan dan kelebihan ini dapat dijadikan sebagai sumber untuk menciptakan produk yang sesuai dengan keinginan dan kebutuhan pelanggan.

Pengaruh Orientasi Pasar Terhadap Kinerja Pemasaran

Pengaruh orientasi pasar berpengaruh positif dan signifikan terhadap kinerja pemasaran. artinya bahwa semakin tinggi orientasi pasar, maka semakin tinggi kinerja pemasaran yang akan dicapai. Perusahaan yang sensitive terhadap upaya-upaya berupa strategi yang berorientasi pada kondisi pasar, tuntutan konsumen, keinginan pelanggan akan dengan sendirinya sensitif juga terhadap perilaku atau strategi yang dilakukan oleh kompetitornya. Perkembangan pemasaran perusahaan saat ini adalah asumsi 
sensitivitas terhadap pesaing. Seiring dengan meningkatnya persaingan global dan perubahan dalam kebutuhan pelanggan dimana perusahaan menyadari bahwa mereka harus dekat dengan pasarnya. Berorientasi pasar juga menjadi salah satu cara untuk bertahan di pasar. Ketika perusahaan berorientasi pada pasar, hal itu menujukkan bahwa perusahaan memperhatikan konsumennya. Perusahaan yang tidak bisa memberikan kepuasan kepada pelanggannya akan mengalami masalah besar. Masalah tersebut dikarenakan dampak keluhan dari pelanggan diabaikan, tidak direspon perusahaan sehingga pelanggan kecewa dan beralih terhadap produk lain. Rata-rata seorang pelanggan yang puas akan memberitahu tiga orang tentang pengalaman produk yang baik, sedangkan rata-rata seorang pelanggan yang tidak puas akan menyampaiakan pengalaman buruknya kepada orang lain.

Hasil ini juga didukung oleh penelitian yang dilakukan oleh Daniel Manek, (2013), Yunita Dwi Pertiwi, Bambang Banu Siswoyo (2016), Bernadeta Dewi Kusuma Jati, Ngatno, (2015), yang menyatakan bahwa orientasi pasar berpengaruh positif signifikan terjadap kinerja pemasaran. Dengan diterapkan orientasi pasar yang dilakukan oleh perusahaan yang meliputi informasi costumer, koordinasi lintas fungsi, dan ketanggapan akan membentuk terminologi orientasi pasar yang dapat digunakan untuk menunjukkan sejauh mana implementasi konsep pemasaran dalam sebuah organisasi yang berorientasi pasar akan memiliki tindakan dan melakukan beberapa aktivitas yang konsisten dengan konsep pemasaran.

Pengaruh Inovasi Produk Terhadap Keunggulan Bersaing

Pengaruh inovasi produk berpengaruh positif dan signifikan terhadap keunggulan bersaing. Artinya bahwa kemampuan perusahaan untuk terus melakukan inovasi terhadap produk-produknya akan menjaga produk tersebut tetap sesuai dengan keinginan dan kebutuhan pelanggan. Dengan demikian, inovasi produk dapat dijadikan sebagai sumber dari keunggulan bersaing perusahaan (Bharadwaj, 1993).

Inovasi sebagai implementing new ideas that create value (O' Regan and Ghobadian, 2005). Yang berarti penerapan ide baru pada suatu produk sehingga menciptakan nilai tambah pada produk tersebut. Jika tidak menciptakan nilai tambah, berarti bukan inovasi. Inovasi adalah barang, jasa, atau ide yang dianggap baru oleh seseorang (Uncles, 2009). Inovasi produk merupakan suatu cara yang penting bagi perusahaan agar tetap dapat beradaptasi dengan pasar, teknologi, serta pesaingan (Dourgerty, 1996). Inovasi produk menunjukkan pada pengembangan dan pengenalan produk baru atau dikembangkan yang berhasil di pemasaran (Nelly et al., 2001). Inovasi produk dapat berupa perubahan desain, komponen dan arsitektur produk. Inovasi produk merupakan satu hal yang potensial untuk menciptakan pemikiran dan imajiinasi orang yang pada akhirnya menciptakan pelanggan (Drucker, 1954 dalam Berthon et al., 1999). Keunggulan kompetitif dapat dicapai melalui fokus pelanggan, pencapaian kualitas, integritas dan tanggung jawab, inovasi dan kreativitas, produksi rendah biaya. Fokus pelanggan dengan cara kurangi birokrasi, puaskan pelanggan, tanggapi keluhan, jalin komunikasi yang baik, lakukan survey kepuasan pelanggan secara rutin dan berkesinambungan. Pencapaian Kualitas, tidak terbatas hanya pada perusahaan besar. Kualitas memegang peranan penting dalam usaha, baik kualitas produk atau jasa. Integritas dan tanggung jawab penuh kepada setiap tuntutan, utamanya pelanggan dan juga kepada pemangku kepentingan. Inovasi dan kreativitas akan membawa keunggulan bersaing. Produksi rendah biaya akan membuat perusahaan mampu bersaing dari sisi harga. Pembeli yang sensitif terhadap harga dan kualitas umunya akan menjadi pertimbangan penting dalam membeli ulang atas suatu produk atau jasa yang bersangkutan (Leonardus Saiman, 2009).

Hasil ini didukung oleh penelitian yang dilakukan oleh Renita Helia, Naili Farida, Bulan Prabawani (2015), Bernadeta Dewi Kusuma Jati, Ngatno, (2015), bahwa inovasi produk berpengaruh signifikan terhadap keunggulan bersaing. Inovasi yang dapat menjadi keunggulan bersaing bagi perusahaan adalah inovasi yang didasarkan pada pengetahuan perusahaan mengenai apa yang diinginkan oleh pelanggan. 
Pengaruh Inovasi Produk Terhadap Kinerja Pemasaran

Pengaruh inovasi produk berpengaruh positif dan signifikan terhadap kinerja pemasaran. Artinya bahwa Inovasi yang dilakukan oleh perusahaan, melalui penciptaan produk baru dan berbeda dari produk yang telah ada atau melakukan perbaikan-perbaikan dari produk yang telah ada, karena inovasi sebagai mekanisme perusahaan untuk beradaptasi dalam lingkungan yang dinamis sehingga menciptakan kinerja layanan yang memuaskan pelanggan kerena inovasi adalah sebagai salah satu variabel penting dalam menentukan kinerja (Baker dan Sinkula, 1999, Wahyono, 2002). Tujuan utama dari inovasi produk adalah untuk memenuhi permintaan pasar sehingga dapat digunakan sebagai keunggulan bersaing bagi perusahaan dan akan menjadi salah satu keunggulan kompetitif terhadap kinerja pemasaran (Han et all., 1998, Hurley \& Hult, 1998). Oleh sebab itu melalui inovasi produk baru dapat meningkatkan penjualan, laba dan keunggulan kompetitif perusahaan (Sivadas \& Dwyer, 2000).

Inovasi produk berkaitan erat dengan peluncuran produk. Salah satu bentuk dari inovasi produk adalah adanya produk baru. Produk baru meliputi produk orisinil, produk yang disempurnakan, produk yang dimodifikasi dan merek baru yang dikembangkan melalui usaha riset dan pengembangan (Haryono dan Marniyati, 2017). Oleh karena itu perusahaan dituntut untuk mampu menciptakan penilaian-penilaian baru, ide-ide baru dan menawarkan produk yang inovatif serta peningkatan kinerja layanan yang memuaskan pelanggan. Inovasi yang berkelanjutan dalam suatu perusahaan merupakan kebutuhan mendasar yang akan mampu menciptakan keunggulan kompetitif, sehingga inovasi merupakan sebuah fungsi penting dari manajemen karena inovasi akan menentukan suatu kinerja bisnis yang superior. (Utaminingsih, 2016).

Temuan ini juga didukung oleh hasil penelitian yang dilakukan oleh Victor Ringhard Pattipeilohy, (2018), Bernadeta Dewi Kusuma Jati, Ngatno, (2015), yang menyatakan bahwa inovasi produk berpengaruh signifikan terhadap kinerja pemasaran.

Pengaruh Keunggulan Bersaing Terhadap Kinerja Pemasaran

Pengaruh keunggulan bersaing berpengaruh positif dan signifikan terhadap kinerja pemasaran. Artinya bahwa menghadapi kondisi persaingan yang ketat maka perusahaan juga harus menciptakan keunggulan bersaing yang merupakan strategi yang menguntungkan bagi perusahaan yang melakukan kerjasama untuk berkompetisi lebih efektif dalam pasar (Dewi 2006, Djodjobo dan Tawas, 2014). Keunggulan bersaing berkaitan dengan cara bagaimana perusahaan memilih dan benar-benar dapat melaksanakan strategi generic ke dalam praktik. Semua bagian yang ada di dalam organisasi, baik yang berupa sumber daya maupun aktivitas dapat menjadi keunggulan bersaing (Prakoso, 2005). Keunggulan bersaing dapat dicapai apabila perusahaan mampu memberikan nilai yang lebih kepada pelanggan dari apa yang diberikan oleh pesaingnya. Keunggulan bersaing dapat berasal dari berbagai aktivitas perusahaan seperti dalam mendesain, memproduksi, memasarkan, menyerahkan, dan mendukung produknya dan diarahkan guna mendukung penciptaan kinerja perusahaan yang berbiaya rendah dan memiliki perbedaan (diferensiasi).

Temuan dari Li (2000) menyatakan bahwa adanya pengaruh positif antara keunggulan bersaing dengan kinerja yang diukur melalui volume penjualan, tingkat keuntungan, pangsa pasar, dan return on investment. Selanjutnya temuan dari Dewi (2006) yang menemukan bahwa keunggulan bersaing yang dimiliki perusahaan semakin meningkatkan kinerja perusahaan dalam bidang pemasaran. Kedua temuan ini semakin mempertegas peran variabel keunggulan bersaing dalam meningkatkan kinerja pemasaran perusahaan. Namun penelitian dari Gozali, et., all (2015) menyatakan bahwa sebaliknya kinerja pemasaran yang mempengaruhi keunggulan bersaing, atau dengan kata lain bahwa semakin baik kinerja pemasaran akan semakin meningkatkan keunggulan bersaing dari perusahaan.

Keunggulan bersaing merupakan nilai yang mampu diciptakan oleh perusahaan untuk konsumennya. Keunggulan bersaing menurut adalah cara terpenuhi jika pelanggan memperoleh perbedaan yang konsisten dalam attribute yang terpenting dari produk yang dihasilkan dibandingkan 
pesaingnya, dimana perbedaan tersebut merupakan dampak langsung dari kesenjangan/ kemampuan antara produsen dan pesaingnya (Suendro, 2010). Keunggulan bersaing merupakan sebuah nilai pada perusahaan dari hasil pengimplementasian strateginya sehingga perusahaan tersebut memiliki penghematan biaya yang lebih besar dan nilai lebih dibanding dengan pesaingnya. Keunggulan tersebut merupakan salah satu penguat daya tawar perusahaan yang lebih kepada konsumen. Keunggulan bersaing dapat diwujudkan melalui penciptaan keunikan yang dilakukan pada desain produk maupun kemasan, kualitas proses produksi yang lebih baik, pemasaran yang lebih menarik, pelayanan penjualan yang lebih memuaskan konsumen, dan lain sebagainya (Hartanty dan Ratnawati, 2013).

Temuan dari Djodjobo dan Tawas (2014) menyatakan bahwa adanya pengaruh yang positif dan signifikan dari keunggulan bersaing terhadap kinerja pemasaran, yang menyatakan bahwa Keunikan atribut dalam produk serta kualitas produk nasi kuning dan harga masih sesuai dengan kemampuan konsumen membuat konsumen mau berkunjung, melakukan pembelian. Jika suatu usaha tidak memiliki hal unik atau nilai berbeda maka tingkat penjualan, keuntungan serta tingkat berkunjung konsumen dalam suatu usaha belum tentu dapat meningkat secara superior. Hasil penelitian dari Basuki et all.,(2014) menemukan bahwa strategi keunggulan bersaing mampu mendukung kinerja pemasaran perusahaan/indsutri Usaha Kecil semakin meningkat/baik.

Pengaruh Orientasi Pasar terhadap Kinerja Pemasaran Melalui Keunggulan Bersaing

Pengaruh orientasi pasar terhadap kinerja pemasaran berpengaruh positif melalui keunggulan bersaing. Artinya bahwa Jhonson et al. (2009) menyatakan bahwa keunggulan bersaing mampu memediasi antara orientasi pasar terhadap kinerja. Hasil penelitian Basuki dan Rahmi (2012) menunjukkan bahwa strategi keunggulan bersaing sebagai variabel moderasi mempunyai peran yang cukup penting dalam mendukung pelaksanaan oreintasi pasar untuk meningkatkan kinerja pemasaran. Didukung dengan penelitian Zhou et al. (2009) menyatakan bahwa Hubungan orientasi pasar tidak secara langsung berhubungan dengan kinerja pemasaran, namun melalui keunggulan bersaing.

Hasil penelitian ini didukung oleh Bernadeta Dewi Kusuma Jati, Ngatno, (2015) bahwa orientasi pasar berpengaruh terhadap kinerja pemasaran melalui keunggulan bersaing. Artinya bahwa orientasi pasar sangat penting dalam manajemen pemasaran modern (Narver dan Slater, 1990). Perusahaan yang berorientasi pasar dinilai memiliki pengetahuan tentang pasar yang lebih tinggi serta memiliki kemampuan berhubungan dengan nasabah lebih baik, kemampuan ini dipandang mampu menjamin perusahaan untuk memperoleh keuntungan yang lebih tinggi dibandingkan dengan perusahaan yang kurang berorientasi pasar (Kirca. 2005).

Pengaruh Inovasi Produk terhadap Kinerja Pemasaran Melalui Keunggulan Bersaing

Pengaruh inovasi produk terhadap kinerja pemasaran berpengaruh positif melalui keunggulan bersaing. Jhonson et al. (2009) menyatakan bahwa inovasi mampu memediasi antara orientasi pasar terhadap kinerja. Inovasi adalah variabel mediator antara orientasi pasar dan kinerja dari perusahaan (Olavarrieta \& Friedmann, 2008). Altuntas et al. (2013) menyatakan bahwa inovasi sangat tergantung pada orientasi pasar dan akan memainkan peran sebagai mediator untuk mendorong kinerja organisasi.

Sukarmen (2013) Inovasi produk merupakan sesuatu yang dapat dilihat sebagai kemajuan fungsional produk yang dapat membawa produk selangkah lebih maju dibandingkan dengan produk pesaingnya. Bagi perusahaan kecil dan menengah inovasi produk merupakan hal yang penting bagi kelangsungan bisnis secara berkelanjutan dan upaya untuk melakukan inovasi produk merupakan fungsi penting dari pihak manajemen suatu perusahaan karena inovasi produk dapat menentukan suatu kinerja pemasaran yang berkualitas (Nasir, 2017).

Hasil penelitian ini didukung oleh Bernadeta Dewi Kusuma Jati, Ngatno, (2015) bahwa Inovasi produk berpengaruh terhadap kinerja pemasaran melalui keunggulan bersaing. Artinya bahwa penciptaan 
produk-produk pendukung yang memiliki rasa yang berbeda dengan yang dimiliki kompetitor serta produk-produk pendukung yang memiliki bentuk yang berbeda dengan produk kompetitor membuat konsumen beranggapan bahwa usaha tersebut memiliki banyak pilihan produk dan layak untuk dikunjungi.

Keterbatasan Penelitian

Berdasarkan hasil penelitian yang telah dikemukakan, perlu diketahui bahwa penelitian ini memiliki keterbatasan antara lain :

1. Penelitian ini hanya difokuskan pada pengolah rumput laut di Kabupaten Wakatobi, sehingga kedepan dapat melakukan penelitian dengan lingkup yang lebih luas.

2. Indikator yang digunakan pada masing-masing variabel masih terbatas, sehingga masih ada beberapa hal yang belum tercakup dalam pembahasan dan masih perlu dikembangkan lebih lanjut seperti pada variabel lingkungan.

3. Dalam penelitian ini lebih menitiberatkan kajian pada vriabel orientasi pasar, inovasi produk, keunggulan bersaing dan kinerja pemasaran yang lebih terfokus pada tanggapan atau penilaian petani pengolah (self assisment), sehingga masih terbuka adanya subyektivitas di dalam memberikan tanggapan.

Berdasarkan beberapa keterbatasan yang dikemukakan di atas, maka direkomendasikan pada penelitian selanjutnya untuk memperluas kajian dengan menambahkan variabel-variabel lain baik variabel eksogen, endogen dan intervening, atau menambah/mengganti indikator yang akan digunakan pada penelitian selanjutnya seperti orientasi kewirausahaan, nilai inovasi.

Kesimpulan

1. Ada hubungan positif yang signifikan antara orientasi pasar terhadap keunggulan bersaing. Dengan demikian penelitian ini membuktikan bahwa orientasi pasar memiliki pengaruh positif terhadap keunggulan bersaing. Perusahaan yang menerapkan orientasi pasar memiliki kelebihan dalam hal pengetahun pelanggan dan kelebihan ini dapat dijadikan sebagai sumber untuk menciptakan produk yang sesuai dengan keinginan dan kebutuhan pelanggan.

2. Ada hubungan positif yang signifikan antara orientasi pasar terhadap kinerja pemasaran. Semakin meningkat orientasi pasar maka kinerja pemasaran semakin meningkat. Arrtinya, perusahaan yang sensitive terhadap upaya-upaya berupa strategi yang berorientasi pada kondisi pasar, tuntutan konsumen, keinginan pelanggan akan dengan sendirinya sensitif juga terhadap perilaku atau strategi yang dilakukan oleh kompetitornya. Perkembangan pemasaran perusahaan saat ini adalah asumsi sensitivitas terhadap pesaing.

3. Ada pengaruh positif dan signifikan antara inovasi produk terhadap keunggulan bersaing. Hasil ini membuktikan bahwa inovasi produk dapat dijadikan sebagai salah satu sumber keunggulan bersaing. Perusahaan yang mampu mendesain produknya sesuai dengan keinginan pelanggan akan mampu bertahan di tengah persaingan karena produknya yang tetap diminati oleh pelanggan. Kemampuan perusahaan untuk terus melakukan inovasi terhadap produkproduknya akan menjaga produk tersebut tetap sesuai dengan keinginan dan kebutuhan pelanggan.

4. Ada pengaruh positif dan signifikan antara inovasi produk terhadap kinerja pemasaran. Inovasi dapat sebagai konversi pengetahuan dan ide-ide ke dalam manfaat yang memiliki nilai komersial atau sosial, dan dibuktikan oleh produk yang baru atau yang ditingkatkan.

5. Ada pengaruh positif dan signifikan antara keunggulan bersaing terhadap kinerja pemasaran. Hal ini menunjukkan bahwa kemampuan perusahaan untuk bersaing dengan perusahaan lainnya ternyata berdampak pada peningkatan kinerja pemasaran perusahaan tersebut. 
Saran

1. Perusahaan harus bisa membangun budaya orientasi pasar sebagai acuan menciptakan inovasi berkelanjutan.

2. Perilaku ini diperlukan dalam rangka berbagi informasi yang diperlukan didalam merencanakan strategi perusahaan.

3. Kesempatan untuk belajar ataupun berbagai pelatihan diperlukan untuk meningkatkan daya kreativitas.

Daftar Pustaka

Akimova, Irina, 1999,"Development of Market Orientation and Competitiveness of Ukrainian Firm”,European Journal of Marketing, p.1128-1146.

Amabile, Teresa, M dkk., "Assesing The Work Environment for Creativity", Academy of Management Journal, p. 1154-1184.

Baker, William E., dan James M. Sinkula, 1999. "The Synergistic Effect of Market Oriented and Learning Organization on Organization Perfomance". Journal of The Academy Marketing Science. p. 411-427.

Bharadwaj, Sundar G, P.R. Varadarajan, dan Jihn Fahy, 1993, Sustainable Competitive Advantage in Service Industries: A Conceptual Model and Research Propositions, Journal of Marketing, Vol.57, Oktober, p. 83-99

Calantone, Roger J, Benedetto, C. Anthony dan Bhoovaraghavan, Sriraman, 1994. "Examining the Relationship between Degree of Innovation and New Product Succes", Journal of Business Research, p. $143-148$.

Cooper , Robert G., 2000. “ Product Inovation and Technology Strategy", Journal Research Technology Management, p. $38-41$.

Craven, David W, 1996. "Pemasaran Strategis", Jilid 1, Suatu Terjemahan, Erlangga, Jakarta.

Daniel Manek, (2013); Analisis pengaruh orientasi pasar terhadap kinerja pemasaran pada perusahaan pengolahan di kota Semarang.Jurnal Sains Pemasaran Indonesia, Volume XII, No. 2, September 2013, halaman $121-148$

Droge, Cornelia dan Shownee Vickery, 1994. "Source And Outcomes Of Competitive Advantage : An Explanatory Study In The Furniture Industri”. Decision Sciences, p. $669-689$.

Day, G. S., \& Wensley, R. (1988). “Assesing Advantage : A Framework for Diagnosing Competitive Superiority", Journal of Marketing, p. 1-20.

Despande, R., Farley, J. U., \& Frederick E. Webster, J. (1993), "Coorporete Culture , Customer Orientation, and Innovativeness in Japanesse Firm”, Journal of Marketing, p. 2327. 
Ferdinand, Augusty., 2000b. "Structural Equation Modelling Dalam Penelitian Manajemen". Seri Pustaka Kunci No. 02 Semarang : Program Magister Manajemen Universitas Diponegoro (Agustus).

Ferdinand, Augusty., 2003. "Sustainable Competitive Advantage : Sebuah EksplorasiModel konseptual". Fakultas Ekonomi Universitas Diponegoro. Semarang

Gatignon, Hubert dan Jean - marc Xuereb, 1997, "Strategic Orientation of The Firm and New Product Performance", Journal of Marketing Research. p.77 - 79

Hair , Joseph F. JR., Rolph E. Anderson, Ronald L. Tatham, William C. Black,1995. "Multivariate Data Analysis With Readings", $4^{\text {th }}$ Edition, Prentice Hall, New Jersey.

Han, Jin K, Narnwoon Kim,and Rajenbdra K Srivastava, 1998, “ Market Orientation an Organization Performance : Is Innovation Missing Link?" Journal of Marketing . p. 42 54

Hunt, J. B., and Wallace, J. 1997. " A Competence - based approach to Assesing Managerial Performance in Australian Context", Asian Pacific Journal of human Resources,p. 52 -66

Han., Jin K. Srivastara., 1998, "Contomer-led and Market Oriented Let's Not Confuse The Two", Strategy Management Journal. pp. 1001-1008.

Jaworski,B.J., \& Kohli, A. K. 1993. "Market Orientation : Antecedents and Consequences", Journal of Marketing, p. 53-70

Kohli ,A. K., \& Jaworski, B. J., 1990. "Market Orientation : The Construct, Research Marketing, pp. 1 - 18

Li, Tiger dan Calantone, Roger J, 1998. "The Impact of Market Knowledge Competence on New Product Advanrage : Conceptualization and empirical Examination", Journal of Marketing, p. 13 - 29

Li, Ling X, 2000, An Analysis of Sources of Competitiveness and Performance of Chinese Manufacturers, International Journal of Operation and Production Management, Vol.20, No.3

Pelhan, Alfred M., 1997. "Mediating Influensure on The Relationship, Between Market Orientation anf Profability in Small Industry Firm". Journal of Marketing Teory and Practice, Sumer, 55-76.

Renita Helia, Naili Farida, Bulan Prabawani (2015); Pengaruh Orientasi Pasar dan Orientasi Kewirausahaan Terhadap Keunggulan Bersaing Melalui Inovasi Produk sebagai Variabel Antara (Studi Kasus pada IKM Batik di Kampung Batik Laweyan, Solo). Diponegoro Journal Of Social And Political Of Science Tahun 2015, Hal. 1-11

Robert, F. Hurley and G. Thomas, M. Hult., 1998. "Innovation, Market Orientation, and Organization Learning : An Integration and Empirical Examination" Journal of Marketing. Vol. 62 Juli 1998. Pp. 42-54. 
Sandy d, Jap. 1999., "Pie-Expansion Efforts : Collaboration Processes in Buyer Supplier Relationship". Journal of Marketing Research Vol. XXXVI November 1999, pp 461-475.

Slater, S. F. and Narver, J. C., 1995, "Market Orientation and The Learning Organization". Journal of Marketing. Vol. 59 p.63-74.

Slater, S. F. and Narver, J. C., 1994. "Does Competitive Environtment Moderrate the Market Orientation Performance Relationship?", Jornal of Marketing, 58 (January), pp.46-55

Victor Ringhard Pattipeilohy, 2018; Inovasi produk dan keunggulan bersaing: Pengaruhnya terhadap Kinerja Pemasaran (Studi pada usaha nasi Kuning di Kelurahan batu Meja Kota Ambon). JURNAL MANEKSI VOL 7, NO. 1, JUNI 2018.

Wahyono, 2002, Orientasi Pasar dan Inovasi: Pengaruhnya Terhadap Kinerja Pemasaran, Jurnal Sains Pemasaran Indonesia, Vol.1, No.1, Mei

William E, Baker, James M, Sinkula, 1999, "Learning Orientation, Market Orientation and Innovation : Integrating and Extanding Models of Organization Perfomance". Jounal of Marketing Focused Management, 4, 295-308

William E, Baker, James M, Singkula, 2002. Market Orientation, Learning Orientation and Product Innovation : Delving into The Organization's Black Box. Jounal of Marketing Focused Management, pp. 5-23.

Yunita Dwi Pertiwi, Bambang Banu Siswoyo (2016); Pengaruh orientasi pasar terhadap kinerja pemasaran pada UMKM kripik buah di Kota batu. Menakar Peran Profesi sebagai Engine of Reform dalam Pembangunan Global Berkelanjutan. ISSN 2460-0784 